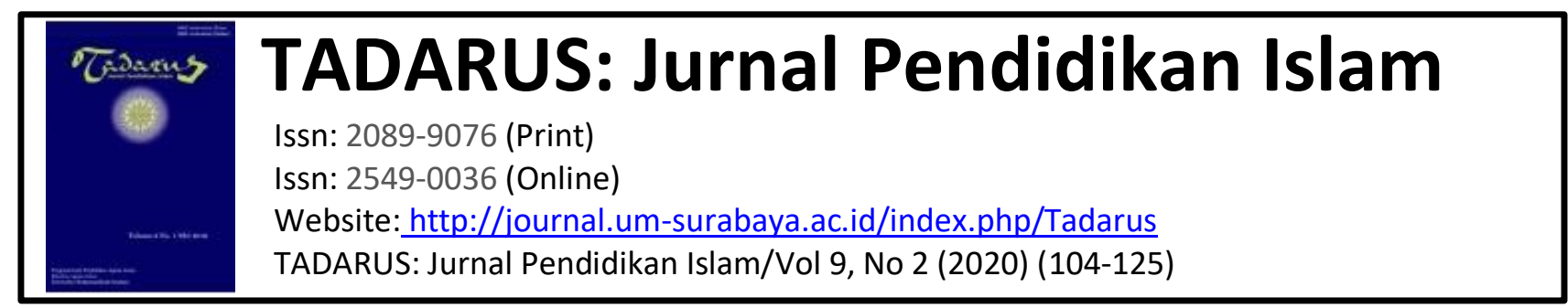

\title{
MODEL PENGAJARAN LANGSUNG MEDIA PERMAINAN ULAR TANGGA MATERI NAMA MALAIKAT DAN TUGASNYA DI SDN NGEMBUNG CERME GRESIK
}

\author{
Asrori \\ asrori@fai.um-surabaya.ac.id
}

\begin{abstract}
Abstrak
Tujuan dari penelitian tindakan kelas ini adalah untuk mengetahui: (1) keterampilan siswa dalam menerapkan model pengajaran langsung dengan menggunakan permainan ular tangga, (2) kinerja siswa selama menggunakan permainan ular tangga dalam pengajaran langsung, dan (3) peningkatan hasil belajar siswa. Penelitian ini merupakan penelitian tindakan kelas (PTK). Subyek penelitian ini adalah siswa kelas IV SDN Ngembung Cerme Gresik.

Berdasarkan hasil penelitian disimpulkan bahwa: (1) Penerapan Model Pengajaran Langsung dengan menggunakan permainan ular tangga berpengaruh positif terhadap hasil belajar siswa, peningkatan ketuntasan hasil belajar siswa tiap putaran yaitu untuk putaran I sebesar 53,85\%, putaran II sebesar $71,79 \%$, sedangkan pada putaran III sebesar $87,18 \%$, (2) Keterampilan siswa diperoleh dari kinerja siswa selama menerapkan media permainan ular tangga sebagai umpan balik siswa dalam pengajaran langsung mengalami peningkatan, dan (3) Keterampilan guru dalam menerapkan penilaian guru tiap putaran mengalami peningkatan . Pada putaran pertama memperoleh nilai ratarata 2,56, pada putaran kedua dengan nilai rata-rata 2,85 , dan pada putaran ketiga memperoleh nilai rata-rata 3,54.
\end{abstract}

Kata kunci: Pengajaran Langsung, Media Permainan Ular Tangga

\section{Pendahuluan}

Pembelajaran merupakan upaya yang sistematis dan sistemik untuk memfasilitasi dan meningkatkan proses belajar, maka kegiatan pembelajaran berkaitan erat dengan hakikat dan jenis belajar serta hasil belajar tersebut. Pembelajaran harus menghasilkan belajar, tapi tidak semua proses balajar terjadi karena pembelajaran. Proses balajar juga terjadi dalam konteks interaksi sosial kultural dalam lingkungan masyarakat. Pembelajaran tidak hanya terjadi dalam lingkungan pendidikan formal, tapi bisa terjadi di luar sekolah. Proses belajar dan pembelajaran bisa terjadi dimana saja, kapan saja tidak dibatasi jarak, ruang, waktu. ${ }^{1}$

\footnotetext{
${ }^{1}$ Asrori, Inovasi Belajar Dan Pembelajaran: Teori Aplikatif (Surabaya: UMSurabaya Press, 2019), xi.
} 
Tujuan pembelajaran pada dasarnya merupakan harapan, yaitu apa yang diharapkan dari siswa sebagai hasil belajar. Robert F. Meager memberi batasan yang lebih jelas tentang tujuan pembelajaran, yaitu maksud yang dikomunikasikan melalui peenyataan yang menggambarkan tentang perubahan yang diharapkan dari siswa. $^{2}$ Menurut Daryanto tujuan pembelajaran merupakan tujuan yang menggambarkan tentang pengetahuan, kemampuan, keterampilan, dan sikap yang harus dimiliki siswa sebagai akibat dari hasil pembelajaran yang dinyatakan dalam bentuk tingkah laku yang dapat diamati dan diukur. ${ }^{3}$

Model pengajaran langsung merupakan suatu pendekatan mengajar yang dapat membantu siswa untuk mengembangkan belajar siswa tentang pengetahuan prosedural dan pengetahuan deklaratif, yang dapat diajarkan dengan pola selangkah demi selangkah. Pengetahuan prosedural adalah pengetahuan tentang bagaimana melakukan sesuatu, sedangkan pengetahuan deklaratif adalah pengetahuan tentang sesuatu. Pengajaran langsung adalah model pengajaran yang mempunyai 5 langkah, yaitu menyiapkan siswa menerima pelajaran, demonstrasi, pelatihan terbimbing, umpan balik, dan pelatihan lanjut (mandiri). ${ }^{4}$

Materi pokok Nama Malaikat dan Tugasnya merupakan salah satu materi dalam pelajaran Pendidikan Agama Islam (PAI) yang yang terbilang cukup rumit dengan hafalan-hafalan dan pemahaman yang banyak. Selama ini siswa mengalami kesulitan pada materi ini dan siswa terkadang lupa juga jika materi pelajaran yang telah diberikan tidak diulang-ulang. Suatu pelajaran dapat dibuat menjadi lebih menarik apabila disajikan dengan menggunakan berbagai macam model presentasi yang menarik. Demikian juga bila kegiatan belajar mengajar dikemas dalam permainan sehingga menghasilkan rasa senang bagi siswa. Salah satu contoh adalah penggunaan media permainan ular tangga. Permainan tersebut merupakan permainan yang tidak asing lagi bagi siswa sekolah dasar.

Berdasarkan diskusi peneliti dengan guru PAI Kelas IV, sebagian besar siswa mengalami kesulitan menerima materi pelajaran PAI terlihat dari nilai ujian akhir tiap semester. Metode yang biasanya dipergunakan adalah metode ceramah dan tanya jawab. Oleh karena itu dibutuhkan model pengajaran langsung dengan menggunakan permainan ular tangga sebagai umpan balik sehingga bisa menarik

\footnotetext{
${ }^{2}$ Sumiati dan Asra, Metode Pembelajaran (Bandung: Wacana Prima, 2009), 10.

${ }^{3}$ Daryanto, Evaluasi Pendidikan (Jakarta: Rineka Cipta, 2010), 58.

${ }^{4}$ Muhammad Nur, Pengajaran Langsung (Surabaya: Uni Press, 2000), 7.
} 
belajar siswa.

Karakteristik permainan ular tangga ini antara lain adalah adanya peserta, aturan-aturan main, unsur persaingan dan penentuan pemenang. Permainan ular tangga ini merupakan permainan antar individu dalam satu kelompok. Mereka berkompetisi untuk mencapai nomer tertinggi yaitu 50. Media permainan ular tangga tersebut digunakan dengan tujuan agar siswa aktif memecahkan masalah. Oleh karena itu perlu dicoba pengembangan media permainan ular tangga pada materi Nama Malaikat dan Tugasnya. Dengan harapan siswa lebih sering berlatih dan dapat mempermudah mereka untuk memahami materi pokok tersebut. Dari permasalahan di atas, peneliti ingin menggunakan model pengajaran langsung dengan menggunakan permainan ular tangga agar dapat meningkatkan hasil belajar siswa. Hal ini mendorong peneliti untuk melakukan Penelitian Tindakan Kelas (PTK) dengan judul: Model Pengajaran Langsung Dengan Menggunakan Media Permainan Ular Tangga Materi Nama Malaikat dan Tugasnya di Kelas IV SDN Ngembung Cerme Gresik.

\section{Metode Penelitian}

Penelitian yang dilakukan termasuk jenis penelitian tindakan kelas (classroom action research). Menurut Asrori Penelitian tindakan kelas adalah sebuah kegiatan yang dilaksanakan untuk mengamati kejadian- kejadian dalam kelas terbingkai dalam beberapa waktu atau siklus dengan metode kontekstual artinya variablevariable yang akan dipahami selalu berkaitan dengan kondisi kelas itu sendiri. Penelitian tindakan kelas bukan bertujuan mengungkap penyebab berbagai permasalahan pembelajaran yang dihadapi seperti kesulitan siswa mempelajari pokok pembahasan tertentu, tetapi lebih penting lagi adalah memberikan pemecahan masalah berupa tindakan tertentu untuk meningkatkan kualitas proses dan hasil belajar. $^{5}$

Penelitian ini merupakan Penelitian Tindakan Kelas (Classroom Action Research) dimana suatu kelompok dikenai perlakuan tertentu dengan penerapan model pengajaran langsung dengan menggunakan permainan ular tangga pada materi Perpindahan Panas. Satu putaran penelitian ini terdiri dari 4 tahap yaitu :

\footnotetext{
${ }^{5}$ Asrori \& Rusman, Classroom Acion Research (Purwokerto: Pena Persada, 2020), 5.
} 


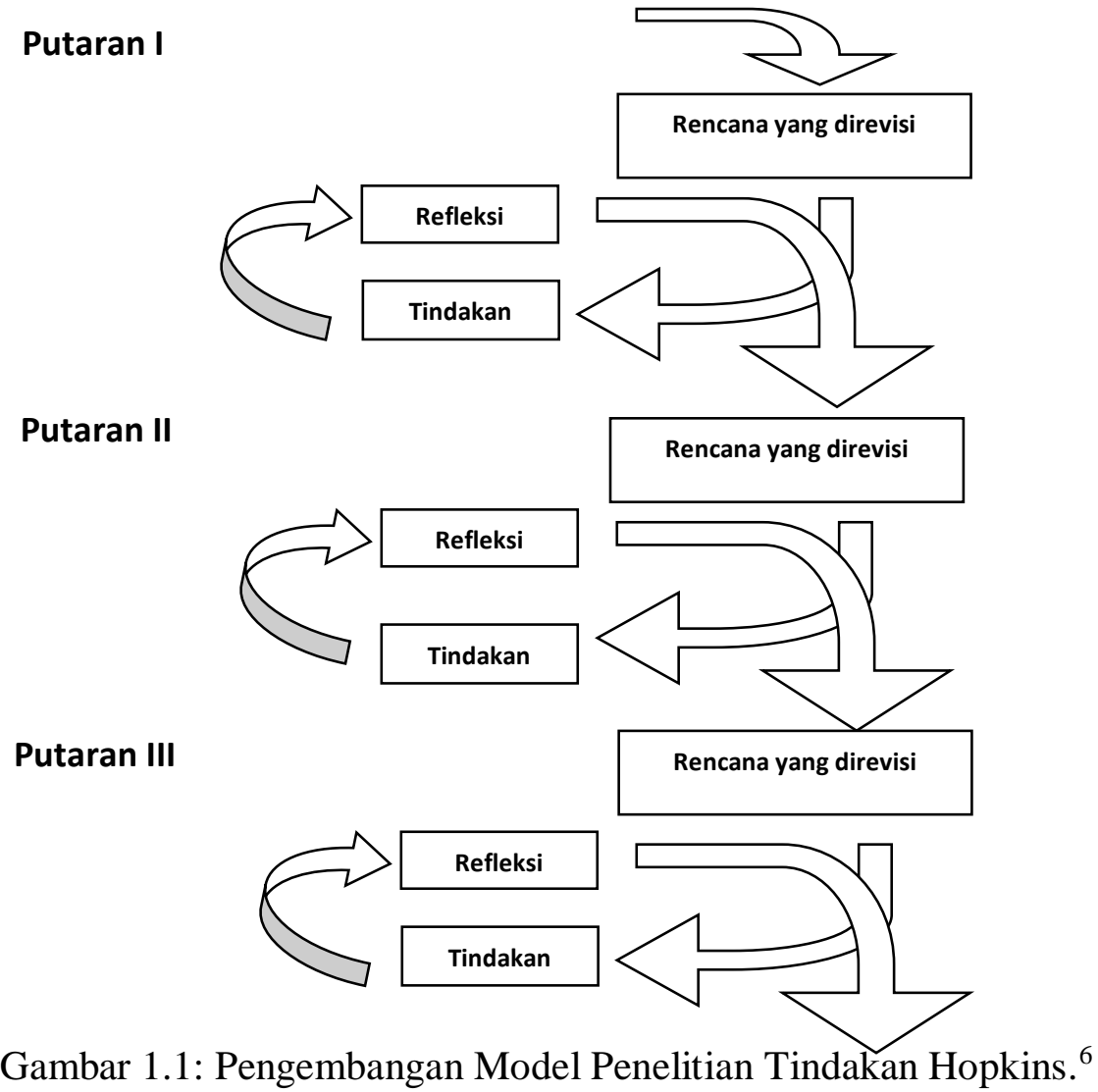

Data yang diperoleh dan observasi aktivitas guru dalam pengelolaan pembelajaran digunakan untuk mengetahui kemampuan guru dalam mengelola kegiatan pembelajaran. Yang dianalisis dengan penilaian sebagai berikut :

Nilai 1,0 = kurang

Nilai 2,0 = cukup

Nilai 3,0 = baik

Nilai $4,0=$ baik sekali

Keberhasilan guru mengelola kelas dapat dilihat dan skor rata-rata setiap putaran dalam PBM.

Skor rata-rata tiap tahap $=\frac{\text { Total skor rata }- \text { rata semua komponentahaptertentu }}{\text { Jumlah } \text { komponen padatahaptersebut }}$

${ }^{6}$ Epon Ningrum, Penelitian Tindakan Kelas (Yogyakarta: Ombak, 2014), 56. 
Rata-rata tersebut dikonversikan dengan kriteria sebagai berikut :

Nilai $(0,00-1,69)=$ kurang

Nilai $(1,70-2,59)=$ cukup

Nilai $(2,60-3,45)=$ baik

Nilai $(3,50-4,00)=$ baik sekali

Data dari pengamatan aktivitas dan kinerja siswa dianalisis dengan menghitung frekuensi dan presentase masing-masing aktivitas yang muncul selama kegiatan pembelajaran, yaitu :

$$
\text { Aktifivitas siswa }=\frac{\sum \text { Frekuensiaktivitassiswa yang muncul }}{\sum \text { Total frekuensiaktivitas }} \times 100 \%
$$

Penilaian aktivitas guru dan siswa masing-masing dilakukan oleh 2 orang pengamat sehingga hasil yang digunakan diperoleh dari rata-rata 2 orang pengamat tersebut.

Analisis angket respon siswa disusun berdasarkan skala Likert. Secara umum teknik dalam pemberian skor yang digunakan dalam kuesioner. Penggunaan skala Likert menurut Sugiyono adalah untuk mengukur sikap, pendapat dan persepsi seseorang atau sekelompok orang tentang fenomena sosial. ${ }^{7}$ Adapun setiap jawaban dihubungkan dengan bentuk pertanyaan atau dukungan setiap yang diungkap dengan kata-kata dalam bentuk angket tersebut kemudian dinilai oleh susunan dengan skala:

$\begin{array}{ll}\text { Untuk penilaian sangat setuju (SS) diberi skor } & =5 \\ \text { Untuk penilaian setuju (S) diberi skor } & =4 \\ \text { Untuk penilaian ragu-ragu (R) diberi skor } & =3 \\ \text { Untuk penilaian tidak setuju (TS) diberi skor } & =2 \\ \text { Untuk penilaian sangat tidak setuju (STS) diberi skor } & =1\end{array}$

Dalam penelitian ini tidak digunakan penilaian ragu-ragu $(\mathrm{R})$ karena menurut Husein dalam Hartatik (2004), pada kategori netral (R) tidak digunakan dari analisis selama responden tidak memberi alasan. Dengan demikian penilaian media permainan ular tangga oleh siswa melalui angket dengan cara memberikan tanggapan $\mathrm{SS}=5, \mathrm{~S}=4, \mathrm{TS}=2$, dan $\mathrm{STS}=1$

Untuk mengetahui aktivitas belajar siswa berpedoman pada lembar observasi indikator penilaian aktivitas belajar siswa, yang dihitung menggunakan rumus

\footnotetext{
${ }^{7}$ Sugiyono, Metode Penelitian Pendidikan Pendekatan Kuantitatif, Kualitatif Dan R\&D (Bandung: Alfabeta, 2014), 132.
} 
ketercapaian tindakan berikut ini. $^{8}$ Angket yang berisi ungkapan pernyataan siswa tentang model pembelajaran langsung dengan media permainan ular tangga yang diterapkan dianalisis menggunakan perhitungan prosentase jawaban responden atas pernyataan dalam angket digunakan rumus sebagai berikut :

$$
\mathrm{P}=\frac{f}{N} \times 100 \%
$$

Dimana : $\mathrm{P}=$ presentasi jawaban responden

$\mathrm{f}=$ jumlah jawaban responden

$\mathrm{N}=$ jumlah responden

\section{Hasil Penelitian dan Pembahasan}

\section{Penerapan Model Pengajaran Langsung dengan menggunakan permainan} ular tangga

\section{a. Tindakan dan Pengamatan Putaran I}

1) Pendahuluan ( \pm 10 menit $)$

Memberikan motivasi kepada siswa dengan meminta siswa untuk menyebutkan nama malaikat yang selalu mengawasi dan mencatat amal perbuatan kita sehari-hari. Kemudian guru memberikan kesempatan kepada siswa untuk menyampaikan jawabannya. Guru menuliskan jawaban dari siswa untuk mendapatkan jawaban yang paling tepat dan benar. Sebelum guru menunjukkan jawaban yang paling benar guru menjelaskan tujuan pembelajaran yang akan dicapai pada putaran pertama.

2) Kegiatan Inti ( \pm 50 menit)

- Guru menjelaskan pengertian malaikat.

- Ketika proses belajar mengajar berlangsung ada salah seorang siswa bertanya apa tugas malaikat jibril? Kemudian ada salah seorang siswa yang lainnya menjawab bahwa tugas malaikat jibril adalah pengantar wahyu kepada para nabi dan rasul Allah SWT.

- Guru membagi siswa menjadi 5 kelompok dengan masing-masing kelompok beranggotakan 7-8 orang.

- Membagikan LKS 1 tentang pengertian malaikat, kemudian meminta siswa mengerjakan LKS 1 sesuai dengan kelompok masing-masing.

\footnotetext{
${ }^{8}$ Suharsimi Arikunto, Manajemen Penelitian (Jakarta: Rineka Cipta, 2000), 246.
} 
- Meminta perwakilan salah satu kelompok untuk menyampaikan hasil mengerjakan LKS 1.

- Memberikan umpan balik kepada siswa berupa permainan ular tangga. Sebelum kegiatan dilaksanakan guru memodelkan dan menjelaskan cara melakukan permainan dan membacakan aturan-aturan dalam permainan. Dalam permainan ini guru dibantu pengamat untuk memperlancar jalannya permainan. Sebelum permainan dimulai guru meminta siswa dalam masingmasing kelompok untuk melempar dadu secara bergiliran dan siapa yang mendapat angka dadu yang banyak maka dia yang bermain terlebih dahulu.

- Kelompok 1, 2, 3, 4 dan 5 mendapatkan sebuah gambar media permainan ular tangga konduksi, satu buah dadu, pion-pion yang berbeda setiap anggota kelompok, dan kartu-kartu soal kemudian memulai melaksanakan permainan ular tangga. Dalam permainan ini ada kelompok yang masih belum paham cara melakukan permainan misalnya kelompok 2 salah satu anggota kelompoknya mendapat giliran bermain kemudian pada saat dadu dilempar dia mendapatkan angka yang berhenti dikartu tangga, dia tidak tahu apa yang harus dilakukan?

- Ketika permainan dimulai ada beberapa kejadian misalnya kelompok 1 ada anggota kelompoknya yang saat dadu dilempar mendapat giliran berhenti di kartu ular kemudian dia mengambil soal pada kartu ular dan salah satu anggota kelompok lain yang tidak mendapat giliran membacakan soal tersebut tetapi siswa itu tidak dapat menjawab soal sehingga dia harus turun ke angka yang ditunjukkan oleh ular. Ada juga salah satu anggota kelompok 4 yang mendapat giliran main kemudian dadu yang dilempar tadi berhenti diangka yang terdapat tangga kemudian salah seorang anggota kelompok yang lainnya yang tidak mendapat giliran bermain membacakan soal kartu tangga yang telah diambil pemain, karena siswa tersebut dapat menjawab soal dengan benar maka siswa tersebut dapat melanjutkan permainan dan dia juga bisa naik tangga sesuai angka yang ditunjukkan tangga permainan.

- Dalam permainan ini hanya 1 kelompok yang bisa mencapai angka tertinggi yaitu 50 dan masih banyak yang belum paham tentang permainan ini. Ada juga salah satu dari anggota kelompok 5 yang tidak melakukan permainan dengan baik atau ramai sendiri. 
3) Penutup ( \pm 5 menit )

Dari akhir pembelajaran guru menyimpulkan materi tentang Pengertian Malaikat dan meminta siswa untuk mengerjakan tes formatif 1 untuk mengetahui pemahaman hasil belajar siswa hari ini.

4) Refleksi

Berdasarkan hasil observasi dan diskusi yang dilakukan observer bahwa hasil pengelolaan pembelajaran langsung pada putaran I ini terdapat beberapa aspek yang perlu diperbaiki :

- Kurangnya motivasi yang diberikan guru ketika proses belajar mengajar berlangsung.

- Guru kurang menguasai kelas sehingga suasana kelas kurang kondusif.

- Kurangnya aktivitas siswa dalam bertanya/berdiskusi pada saat melakukan kegiatan praktikum.

- Kurangnya pemahaman siswa dalam melaksanakan permainan ular tangga.

- Waktu pembelajaran belum sesuai dengan yang dialokasikan pada RPP 1.

5) Revisi

Dari hasil refleksi dan evaluasi tindakan pada putaran I perlu dilakukan revisi untuk tindakan selanjutnya pada putaran II, yaitu:

- Dalam memberikan motivasi kepada siswa seharusnya lebih kreatif lagi sehingga dapat merangsang minat belajar siswa untuk belajar PAI

- Guru harus lebih meningkatkan kemampuan dalam pengelolaan kelas sehingga suasana kelas dapat terkendali dan kondusif.

- Guru harus lebih memperhatikan siswa yang belum paham dalam melakukan percobaan sehingga kegiatan belajar mengajar dapat tercapai.

- Guru perlu memperhatikan waktu yang telah dialokasikan.

\section{b. Tindakan dan Pengamatan II}

1) Pendahuluan ( \pm 10 menit $)$

Memotivasi siswa dengan menunjukkan beberapa nama malaikat yang sering atau sudah diketahui oleh siswa. Kemudian guru mengarahkan siswa pada materi yang akan disampaikan pada pertemuan kali ini. Menyampaikan tujuan pembelajaran yang akan dicapai pada putaran kedua. 
2) Kegiatan Inti ( \pm 50 menit)

- Menjelaskan materi Nama-nama Malaikat dengan media transparansi.

- Ada salah seorang siswa yang bertanya apakah jumlah malaikat hanya sepuluh? Kemudian salah seorang siswa yang lainnya menjawab tidak, masih banyak lagi.

- Membagikan LKS 2 pada para siswa tentang materi nama-nama malaikat, meminta siswa mengerjakan LKS 2 sesuai dengan kelompok yang pada pertemuan pertama sudah dibentuk.

- Meminta perwakilan dari setiap kelompok untuk menyampaikan hasil mengerjakan LKS di depan kelas.

- Meminta para siswa melakukan permainan ular tangga sesuai dengan kelompok pada putaran pertama.

- Setiap anggota kelompok mendapatkan sebuah gambar permainan ular tangga, sebuah dadu, pion-pion yang berbeda tiap anggota kelompok, dan kartu-kartu soal permainan.

- Masing-masing kelompok bermain dengan baik dan bekerja sama dalam anggota kelompok untuk mencapai angka tertinggi terlebih dahulu, karena kelompok yang dapat mencapai angka tertinggi lebih dahulu maka diakhir pembelajaran akan mendapatkan hadiah.

- Ada beberapa kelompok yang anggota kelompoknya masih tidak bisa kondusif dalam melakukan permainan ular tangga.

- Masih ada anggota kelompok 2 yang perlu diperhatikan dalam melakukan permainan ular tangga.

3) Penutup ( \pm 5 menit )

Dari akhir pembelajaran guru menyimpulkan materi tentang konveksi dan meminta siswa untuk mengerjakan tes formatif 2 untuk mengetahui hasil belajar siswa pada pertemuan hari ini

4) Refleksi

Berdasarkan hasil observasi dan diskusi yang dilakukan observer bahwa hasil pengelolaan pembelajaran langsung pada putaran II ini terdapat beberapa aspek yang perlu diperbaiki :

- Suasana kelas cukup terkendali namun harus lebih ditingkatkan lagi dalam hal penguasaan kelas.

- Siswa masih ada yang kurang memahami materi yang diberikan. 
- Masih adanya salah satu kelompok yang belum memahami dalam aturanaturan permainan ular tangga.

\section{5) Revisi}

Dari hasil refleksi dan evaluasi tindakan pada putaran II perlu dilakukan revisi untuk tindakan selanjutnya pada putaran III, yaitu

- Guru masih harus lebih memperhatikan siswa yang belum paham tentang materi yang disampaikan.

- Guru harus memperhatikan para siswa ketika kegiatan permainan dilaksanakan.

- Guru harus lebih mengarahkan dan membimbing siswa pada saat kegiatan belajar mengajar berlangsung khususnya ketika memberikan umpan balik pada para siswa yaitu permainan ular tangga.

\section{c. Tindakan dan Pengamatan III}

1) Pendahuluan ( \pm 10 menit $)$

Pada awal pelaksanaan pembelajaran guru memberikan motivasi pada siswa dengan motivasi awal. Kemudian guru mengarahkan kepada siswa tentang materi yang akan disampaikan pada pertemuan kali ini. Sebelumnya guru menyampaikan tujuan pembelajaran hari ini.

2) Kegiatan Inti ( \pm 50 menit)

- Menyampaikan materi tugas malaikat dengan menggunakan media transparansi.

- Membagikan LKS 3 yaitu tentang tugas malaikat, meminta siswa mengerjakan LKS 3 sesuai dengan kelompok yang telah dibentuk sebelumnya.

- Meminta salah seorang perwakilan kelompok mempresentasikan hasil percobaan.

- Memberikan umpan balik kepada para siswa dengan menggunakan permainan ular tangga sesuai dengan kelompok sebelumnya.

- Masing-masing kelompok mendapatkan gambar permainan ular tangga, sebuah dadu, pion-pion yang berbeda tiap anggota kelompok, dan kartu-kartu soal permainan kemudian memulai permainan.

- Permainan berjalan dengan baik, adanya kerja sama antar anggota kelompok.

- Ada anggota kelompok 2 yang mendapat giliran bermain dan setelah dadu dilempar pionnya berhenti diangka yang terdapat gambar tangga sehingga 
siswa tersebut mengambil kartu soal tangga dan anggota kelompok lain yang tidak mendapat giliran membacakan kartu soal, tetapi soal tersebut tidak dapat dijawab dengan benar sehingga siswa tersebut tidak dapat naik tangga dan harus berhenti diangka yang ditunjukkan di gambar permainan. Begitu seterusnaya sampai ada anggota kelompok yang bisa mencapai angka teringgi dan menjawab soal pinalti dengan benar. Ada anggota kelompok 1 yang dapat mencapai angka tertinggi yaitu 50 terlebih dahulu dari kelompok yang lainnya. Diakhir pembelajaran dia akan mendapatkan hadiah. Permainan berjalan dengan baik yaitu adanya persaingan antar kelompok untuk dapat mencapai angka tertinggi sesuai waktu yang diberikan.

3) Penutup ( \pm 5 menit )

Dari akhir pembelajaran guru menyimpulkan materi tentang konveksi dan meminta siswa untuk mengerjakan tes formatif 3 untuk mengetahui hasil belajar siswa pada pertemuan hari ini

4) Refleksi

Berdasarkan hasil observasi dan diskusi yang dilakukan observer bahwa hasil pengelolaan pembelajaran langsung pada putaran III ini dapat ditarik kesimpulan sebagai berikut :

- Pada putaran III ini kegiatan belajar mengajar secara keseluruhan dikatakan sudah sangat baik.

- Guru mampu mengelola kelas selama kegiatan belajar mengajar berlangsung yaitu pada model pengajaran langsung dengan menggunakan permainan ular tangga sebagai umpan balik yang diberikan kepada siswa.

Proses kegiatan belajar mengajar pada putaran III ini sudah sesuai dengan yang diharapkan, namun masih memerlukan beberapa aktivitas yang harus dilakukan, misalnya guru tetap harus memperhatikan siswa yang nilainya masih rendah atau siswa yang masih belum tuntas hasil belajarnya. Pada putaran III ini guru sudah dianggap menguasai pengelolaan kelas pada saat pembelajaran berlangsung, meningkatnya hasil belajar siswa sesuai dengan meningkatnya hasil nilai tes formatif tiap pertemuan mulai dari putaran I, putaran II sampai dengan putaran III. Hal ini terlihat dari ketuntasan hasil belajar siswa tiap putaran sebagai berikut : 
Tabel 1

Analisis Hasil Tes Formatif Siswa

\begin{tabular}{|c|l|c|c|c|}
\hline \multirow{2}{*}{ No. } & \multicolumn{2}{|c|}{ Karakteristik } & \multicolumn{3}{|c|}{ Jumlah } \\
\cline { 3 - 5 } & & Putaran I & Putaran II & Putaran III \\
\hline 1. & Jumlah Siswa & 39 siswa & 39 siswa & 39 siswa \\
2. & Siswa yang tuntas & 21 siswa & 28 siswa & 34 siswa \\
3. & Siswa yang tidak tuntas & 18 siswa & 11 siswa & 5 siswa \\
4. & Prosentase ketuntasan secara klasikal & $53,85 \%$ & $71,79 \%$ & $87,18 \%$ \\
\hline
\end{tabular}

\section{Penilaian Kinerja Siswa Dalam Melakukan Permainan Ular Tangga}

Data hasil pengamatan kinerja siswa pada putaran pertama dalam melakukan permainan ular tangga pada materi konduksi yang telah dilakukan sebagai berikut :

a. Keeterampilan Siswa Dalam Menggunakan Permainan Ular Tangga

Dalam aspek ini siswa dituntut untuk terampil menggunakan permainan ular tangga dan memahami langkah-langkah permainan ular tangga tersebut sehingga dalam kegiatan belajar mengajar dapat berjalan dengan baik. Kegiatan ini dilakukan dengan cara berkelompok.

b. Kerja Sama Antar Anggota Kelompok

Pada aspek ini siswa dituntu dapat kerja sama antar kelompok dengan sangat baik, kompak dan saling membantu satu sama lain. Hampir semua kelompok dapat bekerja sama dengan baik dan siswa yang kurang aktif dalam kelompok mendapat kategori cukup.

c. Kesiapan Siswa

Kesiapan siswa dalam putaran pertama cukup, karena semua siswa mampu melaksanakan permainan walaupun masih ada yang belum paham dalam permainan.

d. Kedisiplinan Dalam Melaksanakan Permainan Ular Tangga

Pada aspek ini siswa dituntut untuk selalu disiplin, menjaga suasana kelas agar tidak ramai dan mengerjakan tugas yang diberikan dengan baik. Hampir semua siswa mentaati aturan yang ada sehingga kedisiplinan dapat terwujud dengan baik. 
Dari lembar penilaian kinerja siswa didapatkan hasil tabel berikut ini:

Tabel 2

Analisis Penilaian Kinerja Siswa Pada Putaran I

\begin{tabular}{|c|c|c|c|c|c|c|c|c|c|}
\hline No & Aspek & \multicolumn{9}{|c|}{ Skor } \\
\cline { 3 - 10 } & yang & \multicolumn{2}{|c|}{4} & \multicolumn{2}{|c|}{3} & \multicolumn{2}{|c|}{2} & \multicolumn{2}{|c|}{1} \\
\cline { 3 - 10 } & dinilai & Jumlah & $\%$ & Jumlah & $\%$ & Jumlah & $\%$ & Jumlah & $\%$ \\
\hline 1 & A & 0 & 0 & 19 & 49 & 20 & 51 & 0 & 0 \\
\hline 2 & B & 0 & 0 & 8 & 21 & 31 & 79 & 0 & 0 \\
\hline 3 & C & 0 & 0 & 13 & 33 & 26 & 67 & 0 & 0 \\
\hline 4 & D & 0 & 0 & 12 & 31 & 25 & 64 & 2 & 5 \\
\hline
\end{tabular}

Keterangan :

$\mathrm{A}=$ kemampuan menggunakan permainan ular tangga

$\mathrm{B}=$ Kerja sama antar anggota kelompok

$\mathrm{C}=$ Kehadiran siswa

$\mathrm{D}=$ Kedisplinan dalam melaksanakan permainan ular tangga

Kriteria penilaian kategori :

$1=$ kurang $\quad 3=$ baik

2 = cukup 4 = sangat baik

Berdasarkan tabel di atas dapat diketahui pada putaran I belum ada siswa dalam kelompok yang mendapatkan kategori sangat baik pada semua aspek yang dinilai. Pada aspek keterampilan siswa dalam menggunakan permainan ular tangga nilai rata-rata sebesar 2,5 dengan kategori baik. Aspek kerja sama antar anggota kelompok nilai rata-rata sebesar 2,21 dengan kategori cukup. Aspek kehadiran siswa nilai rata-rata sebesar 2,35 dengan kategori cukup. Sedangkan aspek kedisiplinan siswa dalam melaksanakan permainan ular tangga nilai rata-rata sebesar 2,36 dengan kategori cukup.

Data hasil pengamatan kinerja siswa pada putaran kedua dalam melakukan permainan ular tangga pada materi konveksi yang telah dilakukan sebagai berikut :

a. Keterampilan Siswa Dalam Menggunakan Permainan Ular Tangga

Dalam aspek ini siswa dituntut untuk terampil menggunakan permainan ular tangga dan memahami langkah-langkah permainan ular tangga tersebut sehingga dalam kegiatan belajar mengajar dapat berjalan dengan baik. Kegiatan ini dilakukan dengan cara berkelompok.

b. Kerja Sama Antar Anggota Kelompok

Pada aspek ini siswa dituntu dapat kerja sama antar kelompok dengan sangat baik, kompak dan saling membantu satu sama lain. Hampir semua kelompok 
dapat bekerja sama dengan baik dan siswa yang kurang aktif dalam kelompok mendapat kategori baik.

c. Kesiapan Siswa

Kesiapan siswa dalam putaran kedua sudah baik, karena semua anggota kelompok dapat melakukan permainan ular tangga dengan baik meskipun masih ada anggota kelompok yang perlu diperhatikan.

d. Kedisiplinan Dalam Melaksanakan Permainan Ular Tangga

Pada aspek ini siswa dituntut untuk selalu disiplin, menjaga suasana kelas agar tidak ramai dan mengerjakan tugas yang diberikan dengan baik. Hampir semua siswa mentaati aturan yang ada sehingga kedisiplinan dapat terwujud dengan baik.

Dari lembar penilaian kinerja siswa didapatkan hasil tabel berikut ini:

Tabel 3

Analisis Penilaian Kinerja Siswa Putaran II

\begin{tabular}{|c|c|c|c|c|c|c|c|c|c|}
\hline \multirow{2}{*}{ No } & \multirow{2}{*}{$\begin{array}{c}\text { Aspek } \\
\end{array}$} & \multicolumn{9}{|c|}{ Sang } \\
\cline { 3 - 10 } & dinilai & \multicolumn{2}{|c|}{4} & \multicolumn{2}{|c|}{3} & \multicolumn{2}{|c|}{2} & \multicolumn{2}{c|}{1} \\
\cline { 3 - 10 } & Jumlah & $\%$ & Jumlah & $\%$ & Jumlah & $\%$ & Jumlah & $\%$ \\
\hline 1 & A & 0 & 0 & 29 & 74 & 10 & 26 & 0 & 0 \\
\hline 2 & B & 0 & 0 & 24 & 61 & 15 & 38 & 0 & 0 \\
\hline 3 & C & 0 & 0 & 24 & 61 & 15 & 38 & 0 & 0 \\
\hline 4 & D & 0 & 0 & 25 & 64 & 14 & 36 & 0 & 0 \\
\hline
\end{tabular}

Keterangan :

$\mathrm{A}=$ kemampuan menggunakan permainan ular tangga

$\mathrm{B}=$ Kerja sama antar anggota kelompok

$\mathrm{C}=$ Kehadiran siswa

$\mathrm{D}=$ Kedisplinan dalam melaksanakan permainan ular tangga

Kriteria penilaian kategori :

$1=$ kurang $\quad 3=$ baik

$2=$ cukup $\quad 4$ = sangat baik

Berdasarkan tabel di atas dapat diketahui pada putaran II belum ada siswa dalam kelompok yang mendapatkan kategori sangat baik pada semua aspek yang dinilai. Pada aspek keterampilan siswa dalam menggunakan permainan ular tangga nilai rata-rata sebesar 2,75 dengan kategori baik. Aspek kerja sama antar anggota kelompok nilai rata-rata sebesar 2,61 dengan kategori baik. Aspek kehadiran siswa nilai rata-rata sebesar 2,62 dengan kategori baik. Sedangkan aspek kedisiplinan siswa dalam melaksanakan permainan ular tangga nilai rata-rata sebesar 2,65 dengan kategori baik. 
Data hasil pengamatan kinerja siswa pada putaran ketiga dalam melakukan permainan ular tangga pada materi tugas malaikat yang telah dilakukan sebagai berikut :

a. Keterampilan Siswa Dalam Menggunakan Permainan Ular Tangga

Dalam aspek ini siswa dituntut untuk terampil menggunakan permainan ular tangga dan memahami langkah-langkah permainan ular tangga tersebut sehingga dalam kegiatan belajar mengajar dapat berjalan dengan baik. Kegiatan ini dilakukan dengan cara berkelompok.

b. Kerja Sama Antar Anggota Kelompok

Pada aspek ini siswa dituntu dapat kerja sama antar kelompok dengan sangat baik, kompak dan saling membantu satu sama lain. Hampir semua kelompok dapat bekerja sama dengan baik.

c. Kesiapan Siswa

Kesiapan siswa dalam putaran ketiga sangat baik, karena terlihat bahwa semua anggota kelompok mampu melaksanakan permainan ular tangga dengan baik.

d. Kedisiplinan Dalam Melaksanakan Permainan Ular Tangga

Pada aspek ini siswa dituntut untuk selalu disiplin, menjaga suasana kelas agar tidak ramai sehingga permainan dapat berlangsung dkondusif. Hampir semua siswa mentaati aturan yang ada sehingga kedisiplinan dapat terwujud dengan baik.

Dari lembar penilaian kinerja siswa didapatkan hasil tabel berikut ini:

\section{Tabel 4}

Analisis Penilaian Kinerja Siswa Putaran III

\begin{tabular}{|c|c|c|c|c|c|c|c|c|c|}
\hline No & Aspek & \multicolumn{9}{|c|}{ Skor } \\
\cline { 3 - 10 } & $\begin{array}{c}\text { yang } \\
\end{array}$ & \multicolumn{2}{|c|}{4} & \multicolumn{2}{|c|}{3} & \multicolumn{2}{|c|}{2} & \multicolumn{2}{|c|}{1} \\
\cline { 3 - 10 } & dinilai & Jumlah & $\%$ & Jumlah & $\%$ & Jumlah & $\%$ & Jumlah & $\%$ \\
\hline 1 & A & 18 & 46 & 21 & 54 & 0 & 0 & 0 & 0 \\
\hline 2 & B & 9 & 23 & 30 & 77 & 0 & 0 & 0 & 0 \\
\hline 3 & $\mathrm{C}$ & 2 & 5 & 37 & 95 & 0 & 0 & 0 & 0 \\
\hline 4 & $\mathrm{D}$ & 8 & 21 & 31 & 79 & 0 & 0 & 0 & 0 \\
\hline
\end{tabular}

Keterangan :

$\mathrm{A}=$ kemampuan menggunakan permainan ular tangga

$\mathrm{B}=$ Kerja sama antar anggota kelompok

$\mathrm{C}=$ Kehadiran siswa

$\mathrm{D}=$ Kedisplinan dalam melaksanakan permainan ular tangga

Kriteria penilaian kategori :

$$
1=\text { kurang } \quad 3=\text { baik }
$$


2 = cukup 4 = sangat baik

Berdasarkan tabel di atas dapat diketahui pada putaran III sudah ada siswa dalam kelompok yang mendapatkan kategori sangat baik pada semua aspek yang dinilai. Pada aspek keterampilan siswa dalam menggunakan permainan ular tangga nilai rata-rata sebesar 3,50 dengan kategori sangat baik. Aspek kerja sama antar anggota kelompok nilai rata-rata sebesar 3,23 dengan kategori baik. Aspek kehadiran siswa nilai rata-rata sebesar 3,05 dengan kategori baik. Sedangkan aspek kedisiplinan siswa dalam melaksanakan permainan ular tangga nilai rata-rata sebesar 3,19 dengan kategori baik.

\section{Pembahasan}

\section{Pengelolaan Kegiatan Belajar Mengajar}

Hasil pengamatan pengelolaan kelas yang dilakukan guru selama pembelajaran dengan model pengajaran langsung dengan menggunakan permainan ular tangga sebagai umpan balik siswa dapat disajikan sebagai berikut :

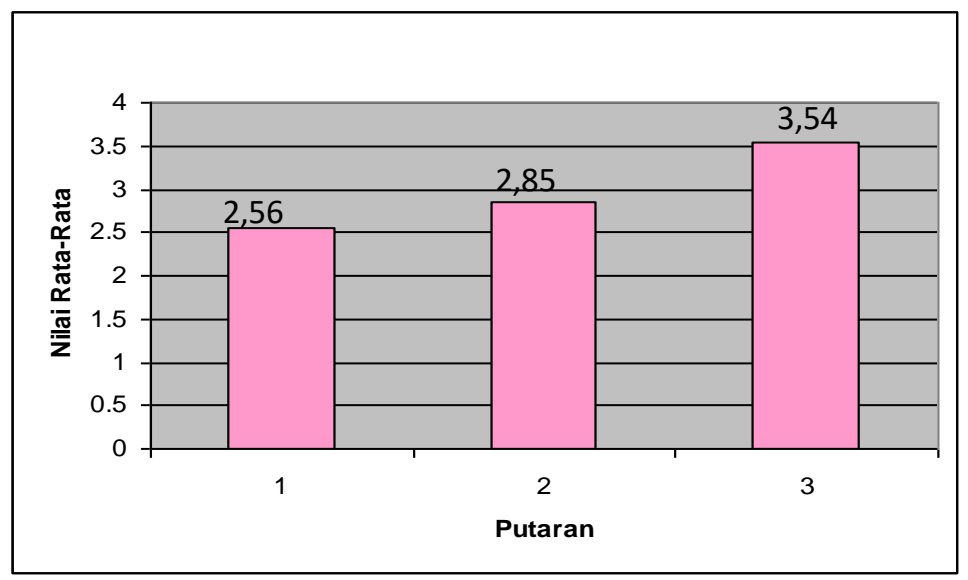

Grafik 1: Hasil pengamatan dalam mengelola kegiatan belajar mengajar

Dari grafik tersebut di atas dapat dilihat pada putaran I guru memperoleh skor rata-rata 2,56 dengan kategori baik. Hasil dari putaran I direfleksikan kemudian direvisi pada putaran II. Pada putaran II kegiatan guru dalam mengelola kegiatan belajar mengajar semakin meningkat, hal ini dilihat dari skor rata-rata guru sebesar 2,85 dengan kategori baik. Pada putaran III skor rata-rata kegiatan belajar mengajar meningkat menjadi 3,54 dengan kategori sangat baik. Dengan meningkatnya hasil pengamatan guru dalam mengelola pembelajaran ini berarti keterampilan guru dalam mengelola pembelajaran dengan menggunakan media permainan ular tangga semakin meningkat. 


\section{Penilaian Kinerja Siswa}

Penilaian kinerja siswa diperoleh dari lembar pengamatan kinerja siswa. Lembar kinerja didasarkan pada kriteria skor yang diamati. Dari hasil analisis didapatkan hasil sebagai berikut :

a. Keterampilan siswa dalam menggunakan permainan ular tangga

Pada aspek ini siswa diminta untuk menunjukkan keterampilan siswa dalam menggunakan permainan ular tangga sesuai dengan apa yang mereka dapat dari pembelajaran. Hasil analisis data keterampilan siswa dalam menggunakan permainan ular tangga dapat disajikan pada grafik sebagai berikut :

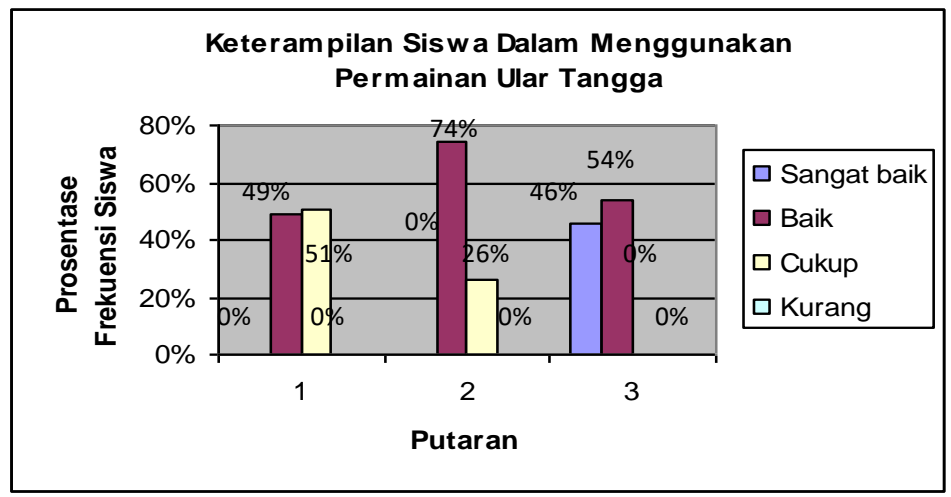

Grafik 2: Keterampilan Siswa Dalam Menggunakan Permainan Ular Tangga

Dalam putaran I sebanyak 19 siswa (49\%) yang memperoleh nilai dengan kategori baik dan 20 siswa (51\%) dengan kategori cukup. Dengan membimbing siswa secara lebih intesif lagi pada saat melaksanakan permainan ular tangga untuk merevisi pembelajaran pada putaran II. Sehingga pada putaran II terjadi peningkatan sebanyak 29 siswa (74\%) dengan kategori baik dan 10 siswa (26\%) dengan kategori cukup. Pada putaran III setelah melakukan revisi dari putaran II terjadi peningkatan sebanyak 18 siswa (46\%) dengan kategori sangat baik dan 21 siswa (54\%) dengan kategori baik.

b. Kerja sama antar anggota kelompok

Pada aspek ini siswa diharapkan saling bekerja sama dalam melaksanakan permainan ular tangga misalnya saling bergantian dalam permainan dan saling bergantian membacakan pertanyaan yang ada pada kartu soal. Hasil analisis data kerja sama antar anggota kelompok dapat disajikan pada grafik sebagai berikut : 


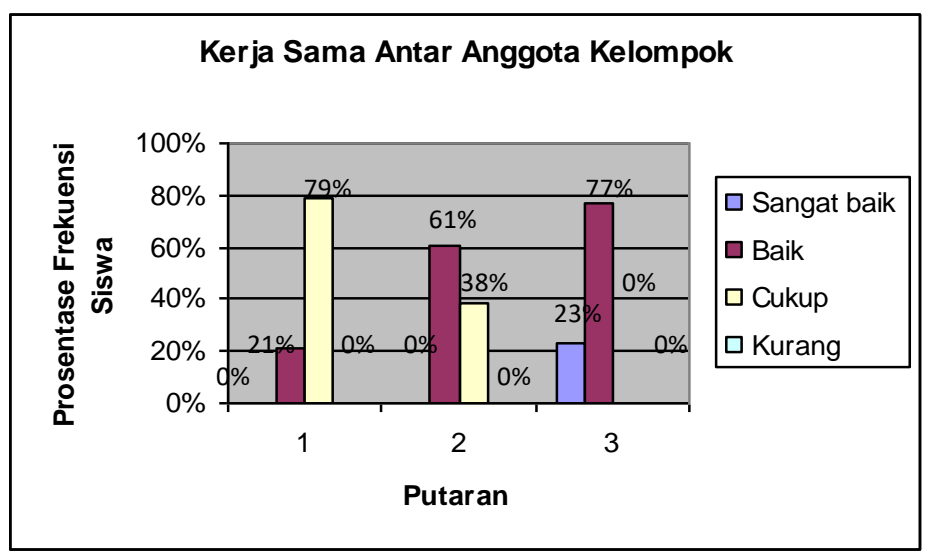

Grafik 3: Kerja Sama Antar Anggota Kelompok

Pada putaran pertama sudah ditunjukkan bahwa siswa bekerja sama dalam melaksanakan permainan ular tangga, sebanyak 8 siswa (21\%) memperoleh nilai dengan kategori baik, dan 31 siswa (79\%) memperoleh nilai dengan kategori cukup. Pada putaran kedua siswa yang memperoleh nilai dengan kategori cukup mengalami penurunan dari putaran pertama yaitu sebanyak 15 siswa (38\%), sedangkan untuk kategori baik mengalami peningkatan yaitu sebanyak 24 siswa (61\%). Pada putaran ketiga setelah melakukan revisi dari putaran kedua terjadi peningkatan sebanyak 9 siswa (23\%) dengan kategori baik dan 30 siswa (77\%) dengan kategori sangat baik.

c. Kesiapan siswa

Pada aspek ini yang dinilai adalah kesiapan siswa ketika melaksanakan permainan ular tangga dan menjawab pertanyaan yang ada pada kartu soal permainan ular tangga. Hasil analisis siswa dalam aspek kesiapan siswa dapat disajikan pada grafik sebagai berikut :

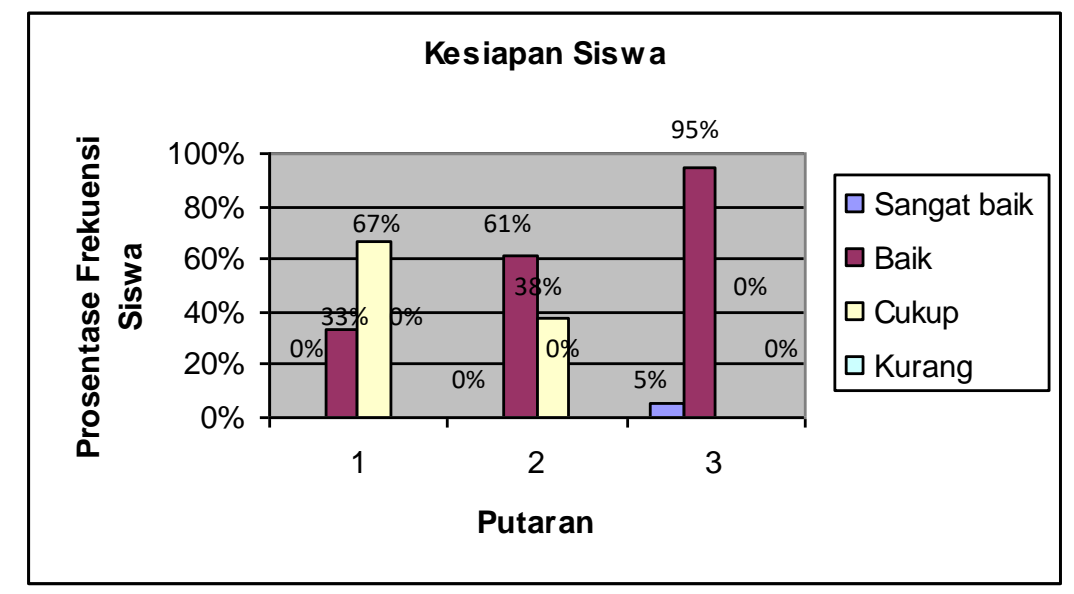

Grafik 4 Kesiapan Siswa 
Berdasarkan grafik di atas pada putaran pertama siswa-siswa merasa senang melaksanakan permainan ular tangga, hal ini disebabkan siswa Kelas IV SDN Ngembung Cerme Gresik tidak terbiasa melaksanakan permainan ular tangga ketika kegiatan belajar mengajar. Siswa yang memperoleh nilai dengan kategori baik sebanyak 13 siswa (33\%), dan 26 siswa (67\%) memperoleh nilai dengan kategori cukup. Pada putaran kedua mengalami peningkatan sebanyak 24 siswa (61\%) memperoleh nilai dengan kategori baik, 15 siswa (38\%) memperoleh nilai dengan kategori cukup. Untuk putaran ketiga mengalami peningkatan ada siswa yang memperoleh nilai dengan kategori sangat baik sebanyak 2 siswa (5\%), dan 37 siswa (95\%) memperoleh nilai dengan kategori baik.

d. Kedisiplinan dalam melaksanakan permainan ular tangga

Pada aspek ini yang dinilai adalah siswa selalu displin, serius, dan menjaga suasana kelas supaya tidak ramai juga harus mengerjakan tugas yang diberikan dengan baik. Hasil analisis siswa pada aspek kedisiplinan dalam melaksanakan permainan ular tangga dapat dsajikan pada grafik sebagai berikut :

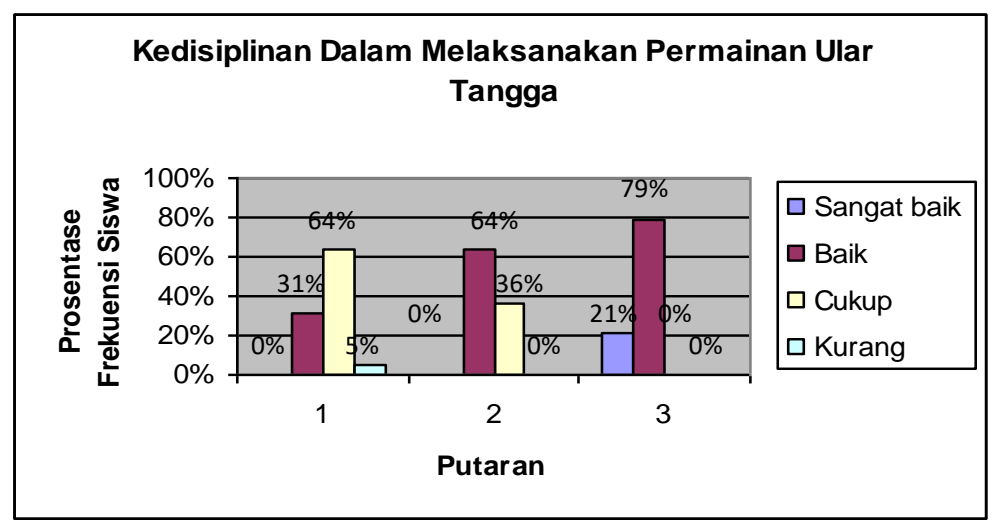

Grafik 5: Kedisiplinan Dalam Melaksanakan Permainan Ular Tangga

Berdasarkan grafik di atas untuk aspek kedisiplinan pada putaran pertama masih belum dikatakan baik, hal ini disebabkan masih ada siswa yang ramai sendiri dalam kelompok yaitu sebanyak 12 siswa (31\%) memperoleh nilai dengan kategori baik, dan 25 siswa (64\%) memperoleh nilai dengan kategori cukup. Pada putaran kedua mengalami peningkatan siswa yang memperoleh nilai dengan kategori baik sebanyak 25 siswa (64\%), dan 14 siswa (36\%) memperoleh nilai dengan kategori cukup. Pada putaran ketiga juga mengalami peningkatan yaitu sebanyak 8 siswa (21\%) memperoleh nilai dengan kategori sangat baik, dan 31 siswa (79\%) memperoleh nilai dengan kategori baik. 


\section{Hasil Belajar Siswa}

Hasil belajar siswa diperoleh dari hasil tes formatif yang dilaksanakan tiap akhir putaran. Ketuntasan belajar secara klasikal masing-masing sekolah mempunyai standart yang berbeda-beda. Untuk standart ketuntasan belajar siswa secara klasikal yang digunakan di Kelas IV SDN Ngembung Cerme Gresik adalah $75 \%$, dan siswa dapat dikatakan tuntas jika nilainya $\geq 65$. Hasil analisis data yang menunjukkan nilai-nilai siswa tiap putaran dapat disajikan pada grafik sebagai berikut :

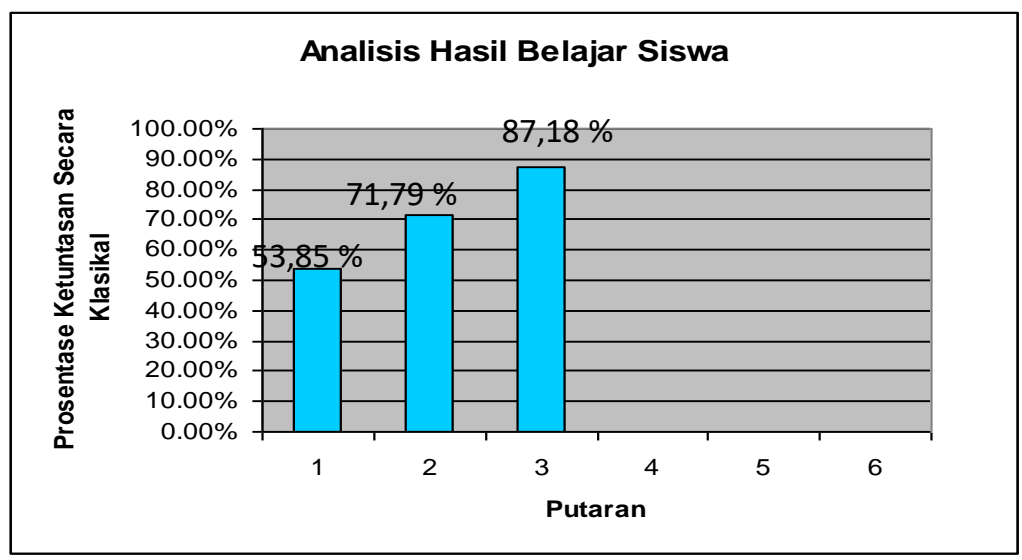

Grafik 6: Analisis Hasil Belajar Siswa

Berdasarkan grafik analisis data tes hasil belajar siswa menunjukkan bahwa pada putaran I terdapat 18 siswa yang belum tuntas karena $\leq 65$. Pada putaran II siswa yang belum tuntas 11 siswa, selanjutnya pada putaran III siswa yang belum tuntas sebanyak 5 siswa. Hasil di atas menunjukkan sudah tercapainya ketuntasan hasil belajar siswa secara klasikal yaitu $75 \%$. Pada setiap putaran terlihat adanya peningkatan prosentase ketuntasan hasil belajar siswa secara klasikal.

\section{Kesimpulan dan Rekomendasi}

\section{Simpulan}

Berdasarkan hasil analisis dan pembahasan data penelitian tentang penerapan metode pengajaran langsung dengan menggunakan permainan ular tangga terhadap hasil belajar siswa, maka dapat disimpulkan: (1) Model Pengajaran Langsung dengan menggunakan permainan ular tangga berpengaruh positif terhadap hasil belajar siswa. Hal ini dapat diindikasikan dengan peningkatan ketuntasan hasil belajar siswa tiap putaran yaitu untuk putaran I sebesar 53,85\%, putaran II sebesar $71,79 \%$, sedangkan pada putaran III sebesar 87,18\%. (2) Keterampilan siswa diperoleh dari kinerja siswa selama menerapkan media permainan ular tangga 
sebagai umpan balik siswa dalam pengajaran langsung mengalami peningkatan. Hal ini dapat diindikasikan dari peningkatan pada aspek keterampilan siswa dalam menggunakan permainan ular tangga untuk putaran I sebesar $49 \%$ dengan kategori baik, putaran II sebesar 74\% dengan kategori baik dan putaran III sebesar $46 \%$ dengan kategori sangat baik. Untuk aspek kerja sama antar anggota kelompok untuk putaran I sebesar $21 \%$ dengan kategori baik, putaran II sebesar $61 \%$ dengan kategori baik dan putaran III sebesar $23 \%$ dengan kategori sangat baik. Untuk aspek kesiapan siswa untuk putaran I sebesar 33\% dengan kategori baik, putaran II sebesar $61 \%$ dengan kategori baik dan putaran III sebesar 5\% dengan kategori sangat baik. Untuk aspek kedisiplinan dalam melaksanakan permainan ular tangga untuk putaran I sebesar 31\% dengan kategori baik, putaran II sebesar 64\% dengan kategori baik dan putaran III sebesar $21 \%$ dengan kategori sangat baik. (3) Keterampilan guru dalam menerapkan penilaian guru tiap putaran mengalami peningkatan . Pada putaran pertama memperoleh nilai rata-rata 2,56, pada putaran kedua dengan nilai rata-rata 2,85, dan pada putaran ketiga memperoleh nilai rata-rata 3,54.

\section{Rekomendasi}

Dalam penelitian ini peneliti merrekomendasi beberapa hal antara lain: (1) Penelitian ini hanya terbatas pada materi pokok Nama Malaikat dan Tugasnya Kelas IV, sehingga perlu dilakukan penelitian lebih lanjut tentang penerapan permainan ular tangga dengan materi pokok PAI yang lain supaya pelajaran PAI menjadi lebih menyenangkan untuk siswa atau ada variasi permainan lain sehingga pembelajaran tidak membosankan.

\section{Referensi}

Arikunto, Suharsimi. Manajemen Penelitian. Jakarta: Rineka Cipta, 2000.

Asra, Sumiati. Metode Pembelajaran. Bandung: Wacana Prima, 2009.

Asrori. Inovasi Belajar Dan Pembelajaran: Teori Aplikatif. Surabaya: UMSurabaya Press, 2019.

Asrori \& Rusman. Classroom Acion Research. Purwokerto: Pena Persada, 2020.

Daryanto. Evaluasi Pendidikan. Jakarta: Rineka Cipta, 2010.

Ningrum, Epon. Penelitian Tindakan Kelas. Yogyakarta: Ombak, 2014. 
Nur, Muhammad. Pengajaran Langsung. Surabaya: Uni Press, 2000.

Sugiyono. Metode Penelitian Pendidikan Pendekatan Kuantitatif, Kualitatif Dan $R \& D$. Bandung: Alfabeta, 2014. 